\title{
家庭排水を経路とした住宅団地からの ビスフェノールAの排出実態
}

\author{
今岡 務 1 - 林 香代子 $2 \cdot$ 上田 徹也 2 - 吉村 友宏 3 \\ 1正会員 広島工業大学教授 環境学部環境情報学科（干731-5193 広島県広島市佐伯区三宅2-1-1） \\ E-mail:timaoka@cc.it-hiroshima.ac.jp \\ 2 広島工業大学大学院 環境学研究科（干731-5193 広島県広島市佐伯区三宅2-1-1） \\ 3菱明技研株式会社（干733-0036 広島県広島市西区観音新町一丁目20番24号）
}

\begin{abstract}
ビスフェノール A （B P A）はプラスチック製品の原材料として使用される有機化学物質であり, 内 分泌攪乱作用が疑われている。本研究では，このB P A 関して住宅団地の家庭排水を経路とした排出 源と排出経路を明らかにすることを目的とした。広島県 A住宅団地の污水処理場における24時間連続調 查と 1 週間継続調査で得られた流入污水の平均 B P A 濃度は0.12-0.22 $\mu \mathrm{g} / \mathrm{L}$ 範囲にあり, B P Aの約 $50 \%$ は，懸濁態として検出された。A住宅団地から B P Aの排出負荷量は，189-333mg/日と算出された。 一方, 洗濯機や食器洗浄機からの排水など数種類の家庭排水およびトイレットペーパーなどからの B P A 排出負荷を調查, 検討した結果, 個々の B P A 負荷の合計は污水処理場への流入負荷の約 $15 \%$ に相当 すると算定され，排水管の内面などその他の B P Aの排出源の調査が必要であることが示唆された.
\end{abstract}

Key Words : endocrine disruptors, bisphenol A, domestic wastewater, discharge load

\section{1. はじめに}

ビスフェノール A (以下, B P A）は，ポリカーボネ 一ト樹脂やエポキシ樹脂の主原料であり，一方で塩化ビ ニル樹脂や塗料の助剤, またコピー機のトナー中の顕色 剂などとして，幅広い用途で使用されている.このB P Aに関しては, 外因性内分泌攪乱作用, いわゆる環境木 ルモン作用が疑われ，動物実験等で生殖・発生毒性を示 唆する報告も多くなされていることから，健康影響的に も注目されている化学物質である ${ }^{1)}$ 。さらに，環境ホ ルモン作用が疑われている物質の中では, ノニルフェノ 一ルとともに水環境中において高い頻度で検出されてお り, 平成 13 年度に環境省により実施された全国調査で は, 171 の水域調査地点のうち, 86 地点 $(50.3 \%)$ で検出 下限以上の濃度の B P Aが検出されている ${ }^{2)}$ 。 ただし, このような B P Aの環境への排出源および排出経路に関 しては, 毒性評価等と比較して十分な知見が得られてい るとは言い難いのが現状である. 安原ら ${ }^{3)}$ や Urase \& Miyashita $^{4)}$ により, 廃衰物最終処分場からの浸出水中 に高濃度に含有されている例が報告され，また，坂本ら は5) 浸出水一の排出源として埋立処分されている塩化 ビニル樹脂を指摘する報告を行っている．しかしながら， 水環境中で広く検出される B P Aの排出源としては, 廃 棄物最終処分場からの排出のみでは説明がつかないと考
えられる. 国土交通省の調査 ${ }^{6)}$ では, 下水処理場の流 入下水中のB P A濃度として 0.04 9.6 $\mu \mathrm{g} / \mathrm{Lが，また}$ 家庭系排水中の值として $0.31 \sim 0.44 \mu \mathrm{g} / \mathrm{L}$ が報告されて おり, 家庭からのB P Aの排出を示唆する結果となって いる. ただし, その排出源に関しては, 食器, 哺乳瓶お よび午製品また歯科材料などからの溶出のように人間の 健康影響の観点から調べた報告 ${ }^{7)}$ は多く見られるもの の, 家庭からの排出量として定量的な評価を行った例は 見当たらない，なお，独立行政法人製品評価技術基盤機 構は, 既往の調査・研究例および独自の調査結果をもと に, わが国における B P A の生産から使用, 廃棄に至る 実態を踏まえた放出シナリオを作成し, 各放出源からの 2000 年度の放出量を見積もっており，水域に関しては 主要なものとして再生紙工場から $120 \sim 50,000 \mathrm{~kg} /$ 年, 下 水処理場から $200 \mathrm{~kg} /$ 年および廃棄物処分場から $30 \mathrm{~kg} /$ 年 という結果を示している8).

一方，最近の調查では，B P A 関しては低用量での 明らかな内分泌攪乱作用は, 認められなかったとする報 告 ${ }^{9)}$ も出されている. しかしながら，この内分泌攪乱 作用の有無に関わらず，化学物質の適正なリスク管理の 観点から, B P Aの水環境への排出源ならびに排出経路 を明らかにすることは重要な課題と考えられる. 本研究 では，とくに家庭功のB P Aの排出に注目し，家庭排 水を経路とした排出実態の定量的な把握ととくに家庭内 
で使用されている家電製品等の機材に注目して主要な排 出源の探索を図ることを目的とし，住宅団地規模での地 域的な B P Aの排出バランスについて調查, 検討を行う こととした.

\section{2. 調査内容および方法}

\section{（1）調査場所および概要}

本研究では, 広島県の $\mathrm{A}$ 団地を対象に, 団地内の特定 地域污水処理場(標準活性污泥法)における流入水と放流 水の水質調查等を実施した. A団地は人口約 6400 人

（男 3100 人，女 3300 人），約 2000 世帯を有する住宅 団地であり，本処理場に流入寸る污水は，家庭排水等生 活系の排水のみである. この $\mathrm{A}$ 団地污水処理場では 4 回 の調査を, また別途家庭内で発生する各種排水等を採取 し, 排水種別の B P A濃度の調査も行った. さらに, 家 庭からのB P A 排出源としてトイレットペーパーの寄与 を想定し，各種原材料から製造されたトイレットペーパ 一を用いた溶出試験も実施した。

\section{（2）A団地污水処理場での調査日時と概要}

A 団地污水処理場における調査は，2時間毎に試料採 取を行う 24 時間連続調查を 2 回ならびに 10 時と 22 時 に試料採取を行う 1 週間連続調查を 2 回, それぞれ実施 した.

24 時間連続調查は，平成 16 年 10 月 21 日 12 時〜 22 日 12 時ならびに平成 17 年 1 月 11 日 12 時〜 12 日 12 時 に実施した. また， 1 週間連続調查は 2004 年 9 月 1 日 10 時〜 8 日 10 時ならびに 11 月 8 日 10 時〜 15 日 10 時 の期間で行った. ただし，11月 7 日(火)は，台風のた め, 10 時の採水を取りやめた. なお, 流入水に関して は, ガラス繊維ろ紙 $(1 \mu \mathrm{m})$ を用いてろ過を行い, そ のろ液を用いて溶存態B P Aを，またろ紙をアセトンで 抽出し, その抽出液から懸濁態B P Aをそれぞれ測定し た.

\section{（3）家庭内排水種別調査}

家庭内での水使用は，用途別に飲用，炊事，洗濯，風 呂, 水洗便所, 洗車等に大別されるが， 1 人 1 日当たり の平均的な使用水量 $(240 \mathrm{~L} /$ 人/日) で見ると, 風呂用 水，水洗便所，洗濯用水および炊事用水がそれぞれ，60, 50，40 および $30 \mathrm{~L} /$ 人/日とされており ${ }^{10)}$ ，これらで $75 \%$ を占めている。 また, 残りの $25 \%$ の使用水量の $50 \%$ は屋外での使用を想定した洗車用水である. したが って, 污水処理場に流入する主要な家庭内排水として, 風呂排水である浴槽およびシャワーでの使用排水, 洗濯 排水である洗濯機からの排水，また炊事排水として食洗
機からの排水に着目し，それぞれ協力が得られた家庭で 試料採取し，B P Aの分析に供した。これらの排水に関 しては，外観上とくに懸濁物質の存在が見られなかった ため，万過処理せず，直接全量を前処理した．表一 1 に， 各試料の採取方法および調查世帯数等をまとめた。 なお, 水洗便所からのB P A 排出に関しては, 次に述べるトイ レットペーパーと人の尿に起因するものを想定し，検討 に加えた.

\section{（4）トイレットペーパーからのB P A 溶出の検討}

水洗便所からの排水に伴う B P Aの排出に関しては, 人の尿に起因寸るものとトイレットペーパーに起因する ものを想定した．尿中のB P A濃度に関しては最近の報 告 ${ }^{11)}$ があり，それを参考とした. トイレットペーパー に関しては，原料の異なるトイレットペーパーを試料と して攪拌溶出試験を行い, B P A溶出量の検討を図った. 供試試料としては，(a) 古紙（5種），(b) 牛乳パック

（1 種），(c)バージンパルプ 100\%（3 種）をそれぞ れ原料として製造された計 9 試料のトイレットペーパー を用いた。

攪拌溶出試験方法は, 各試料 $2 \mathrm{~g}$ を細かく裁断し, ビ 一カーにトイレットペーパーと超純水 $400 \mathrm{~mL}$ L入れ, スターラーにより 1 時間攪拌した。 この攪拌時間は, 調 查対象団地での家庭から污水処理場までの流下時間を想 定したものである.これらの試料溶液は, 懸濁物質が多 いため，ガラス繊維ろ紙を用いて，万過を行った，その ろ液を用いて溶存態B P Aを, またろ紙をアセトンで抽 出し，その抽出液から懸濁態B P Aをそれぞれ測定した.

\section{（5）分析項目および方法}

各種調査の主要な分析項目はB P A とし, 適宜BOD, CODおよびS S の項目を付加した.

B P A J I S 「用水・排水中のビスフェノール A 試 験方法」 ${ }^{12)}$ に準じて, 前処理・抽出を行い, G C - M S（高分解能ガスクロマトグラフ-四重極質量分析計, G C : H P 6890 SERIES 高分解能ガスクロマトグラフ (HP社)，MS：四重極質量分析計（日本電子製））

\section{表 -1 家庭内排水試料の概要}

\begin{tabular}{|c|c|c|c|c|c|}
\hline 排出源 & 排水 & 試料採取方法 & $\begin{array}{l}\text { 調査世帯数 } \\
\text { (試料数) }\end{array}$ & 使用年数 & 使用水量 \\
\hline \multirow{2}{*}{ 風呂 } & 浴槽 & $\begin{array}{l}\text { 浴槽に湯を張り，約6時間後 } \\
\text { の湯を試料として採取した。 }\end{array}$ & 4 & $10 \sim 16$ 年 & $\begin{array}{l}150 \\
\sim 200 \mathrm{~L}\end{array}$ \\
\hline & シャワー & $\begin{array}{l}\text { シャワーからのお湯を, 直接 } \\
\text { 採取した。 }\end{array}$ & 4 & $10 \sim 16$ 年 & - \\
\hline 洗濯 & 洗濯機 & $\begin{array}{l}\text { 洗濯機は数回排水されるの } \\
\text { で, 排水毎に }=150 \mathrm{~mL} \text { 量り， } \\
\text { 混合して1試料とした。 }\end{array}$ & 3 & $8 \sim 11$ 年 & $\begin{array}{l}\text { 1回の洗濯 } \\
\text { で, 150〜 } \\
\text { 180L程度 }\end{array}$ \\
\hline 炊事 & 食器洗浄機 & $\begin{array}{l}\text { 洗濯機と同様, 排水毎に定 } \\
\text { 量を採取しそれを混合して } \\
1 \text { 1試料とした。 }\end{array}$ & 2 & 4. $5 \sim 8$ 年 & $16 \sim 25 \mathrm{~L}$ \\
\hline
\end{tabular}

(注1）洗濯機および食器洗浄機の排水は, 洗濯物および食器を入れずに運転し, 試料を採取した (注2) 使用水量は, 取扱説明書の標準総使用水量である. 
表一2 GC-MSの測定条件

\begin{tabular}{|l|l|}
\hline \multicolumn{1}{|c|}{$\mathrm{GC}$ 条件 } & \multicolumn{1}{|c|}{$\mathrm{MS}$ 条件 } \\
\hline •カラム: $\mathrm{BPX}-5$ & ・イオン化方式 : 電子衝撃イオ \\
$(30 \mathrm{~m} \times 0.25 \mathrm{~mm}, 0.25 \mu \mathrm{m})$ & ン化方式 $(\mathrm{EI}$ 法 $)$ \\
•キャリアーガス: & •イオン源温度 : $230^{\circ} \mathrm{C}$ \\
$\mathrm{He}(2.5 \mathrm{~mL} / \mathrm{min})$ & •電子加速電圧 $: 70 \mathrm{~V}$ \\
•昇温条件: & \\
$60^{\circ} \mathrm{C}(1.0 \mathrm{~min}) \rightarrow 10^{\circ} \mathrm{C} / \mathrm{min}$ & \\
$\rightarrow 280^{\circ} \mathrm{C}(7.0 \mathrm{~min})$ & \\
•試料注入量: $1 \mu \mathrm{L}$ & \\
\hline
\end{tabular}

を用いて測定した。 すなわち，前処理は，試料に塩酸 を加え $\mathrm{pH}$ を約 3 に調整し, 塩化ナトリウムを添加後,

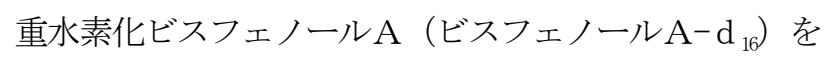
加え, ジクロロメタンで対象物質を抽出した後, 脱水, 濃縮して一定量とした. この濃縮液を目盛り付き共栓試 験管に移し窒素を吹き付け $0.5 \mathrm{~mL}$ まで濃縮した, その後 N, Oービス (トリメチルシリル)トリフルオロアセトアミド (BSTFA)を $200 \mu \mathrm{L}$ 添加し, 約 1 時間放置した.この溶液 に，フェナントレイン内標準液 $\left(1 \mu \mathrm{g} \mathrm{C}_{14} \mathrm{H}_{10}-\mathrm{d}_{10} / \mathrm{mL}\right)$ を 100 $\mu \mathrm{L}$ 加え, 振り混ぜて溶解した後, ジクロロメタンを $1 \mathrm{~m}$ Lまで加え測定試料とした.

測定試料の一定量を $\mathrm{GC}-\mathrm{MS}$ に注入し，検出法に選 択イオン検出法 (S I M) を用いて定量を行った. 表一2 にGC-MSの測定条件を示す.

分析精度に関しては，検量線作成標準液を用いて 5 回 の繰り返し測定を行い，ピーク面積の相対標準偏差を求 め，10\%以内であることを確認した．また，各分析毎に 重水素化ビスフェノール Aの回収率をフェナントレイン 内標準物質として測定し, 回収率が 50〜 120\%であるこ とを確認し，この範囲を超過した時には再測定を行った。 検出下限については，5回以上の繰り返し測定の結果， $0.01 \mu \mathrm{g} / \mathrm{L}$ であった.

なお，懸濁態のB P Aに関しては，J I Sにおいて 「試料中に懸濁物の量が多い場合」の操作として付記さ れている方法に従って，試料をガラス䋊維ろ紙でろ過し， ろ紙上の懸濁物をろ紙ごと超音波洗浄器を用いてアセト ンで 3 回程度溶出し, 溶出液を合わせた後, それを試料 として通常試料と同様な方法で濃縮・分析を行い，測定 值を得た.

BOD，CODおよびS S は下水試験方法 ${ }^{13)}$ に従っ て分析した. すなわち, B OD測定時のDO (溶存酸素) の分析はウインクラー・アジ化ナトリウム変法により実 施し，CODの測定は「 $100^{\circ} \mathrm{C}$ Cおける過マンガン酸力 リウムによる酸素要求量 (酸性法)」により行った。ま た， S Sの測定はガラス䋊維ろ紙法（1 $\mu \mathrm{m})$ によった.

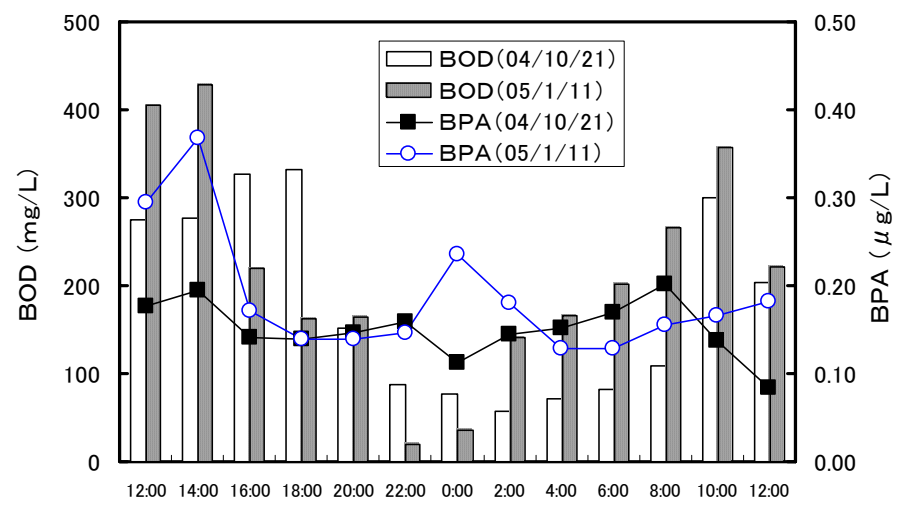

採取時刻

図一 $1 \mathrm{~A}$ 団地污水処理場流入水のB P A 濃度変化 (2004年 10 月 21 日，2005年 1 月 11 日)

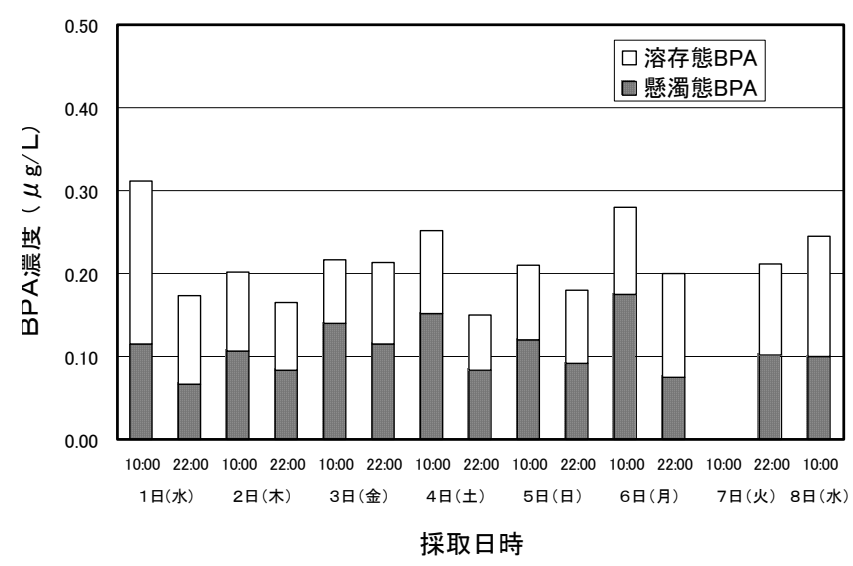

図一２Ａ団地污水処理場流入水のB P A 濃度変化 ( 1 週間連続調查 : 2004 年 9 月 1 日〜 8 日)

\section{3. 調査結果および考察}

\section{（1）A団地污水処理場における調査結果}

2 回の 24 時間連続調査で得られた団地污水処理場流 入水のBODおよびB P A の濃度変動を図ー 1 に示した。 B ODが夜間（22 時〜 6 時） と比較して昼間に明らか に高い值を示したのに対して，B P Aに関しては 14 時 にややピークが認められるものの，BODほどの昼夜の 変動や顕著なピークを確認することはできなかった.

次に，平成 16 年 9 月 1 日から開始した 1 週間連続調 査の結果を図ー2に示した２回の調査を通して，午前 10 時の B P A 濃度が夜間の值をやや上回る傾向が認め られたが，その差はそれほど大きなものではなく, 調査 期間毎での測定值の変動係数で見ても, 検出濃度がやや 低かった 11 月の懸濁態B P A での 0.80 を除けば， 0.20 〜0.35 が得られ，昼夜間および曜日間でのとくに顕著 な変動はないものと考えられた. B P A の検出濃度範囲 は， 9 月の調査で $0.15 \sim 0.31 \mu \mathrm{g} / \mathrm{L} ， 11$ 月の調査では $0.07 \sim 0.23 \mu \mathrm{g} / \mathrm{L}$ であり, 曜日間での大きな差異は見ら れず，国土交通省が 1998～2000 年度に全国 47 力所の下 
水処理場において実施した調査 ${ }^{6)}$ での中央值 $0.53 \mu \mathrm{g} /$ Lと比較するとやや低い值となった。一方，調査日によ って多少異なるが，団地污水中のB P Aのうち，懸濁態 のものがかなりの割合を占めていることが明らかとなっ たＢＰＡそのものは白色固体の物質であり，また溶解 度も $120 \mathrm{mg} / \mathrm{L}\left(25^{\circ} \mathrm{C}\right){ }^{14)}$ とそれほど水に溶け易い物質で はないが，ポリカーボネート樹脂あるいはエポキシ樹脂 などの原料として使用された後の環境への排出形態とし ては，主として溶出試験により評価が行われていること もあり，溶存態のものが主たる形態と考えていた。した がって, 図ー2に示したような懸濁態のB P A の存在は 予想しておらず，推測であるが，トイレットペーパー中 のB P A の存在や団地污水処理場に流入してくる過程で 微小懸濁物質に吸着する可能性などが考えられた。ただ し，図ー3に示すようにこの懸濁態 B P A と S S との間 には，とくに強い相関は認められず，懸濁態B P Aの挙 動を家庭から排出される台所の調理くずや食べ残しなど に起因する懸濁物質と結びつけることは困難と推測され

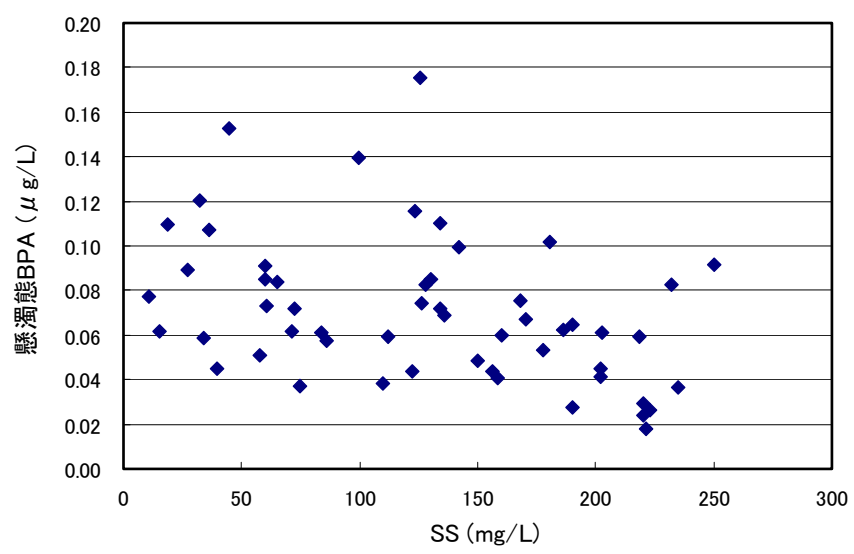

図一3 流入水中の懸濁態B P A と S S の関係
た.

なお，放流水中のB P A濃度は，<0. $01 \sim 0.02 \mu \mathrm{g} / \mathrm{L}$ であり, ほとんどの場合, 検出下限以下の值であった。 前述した国交省による 3 年間の下水処理場での調査結果 においても, 流入下水のB P A濃度の中央值 $0.53 \mu \mathrm{g} / \mathrm{L}$ に対して, 流出水（処理水）の中央值は $0.02 \mu \mathrm{g} / \mathrm{L}$ とな っており, 平均的な B P A 除去率は 96\%程度とされて いる.これらより，下水処理場に流入してくるB P A その処理工程で分解あるいは活性污泥への吸着等により ほぼ除去されるものと考えられた。

本処理場では，放流水量のみ流量データの計測が行わ れているので, B P A の流入負荷の時間変動まで, 考察 することは困難であった，そこで，4回の調査でそれぞ れ得られた流入水の平均 B P A 濃度と日放流水量をもと に，本団地でのB P A排出負荷量ならびに排出原単位を 求め, 表一3にまとめた。

また， 1 週間調査で得られたBOD，COD， S Sの データから, それぞれの排出負荷原単位を算出し, 表一 4 に示した. なお，污水量に関しては，4回の調査結 果からは 1 人 1 日当たりの污水量が $262 \mathrm{~L} /$ 人/日とな り，2回の 1 週間調査の結果を用いた場合でも， $250 \mathrm{~L}$ / 人/日となることから，一般家庭での生活用水としての 1 人 1 日当たりの平均使用水量が 200〜250 L/人/日 ${ }^{10)}$ とされていることと比較すると, やや大きめの值と考 えられたが, 本団地が造成されてから 25 年ほど経過し, 住居者の高齢化が進んでいることなども関係している ことが推測された。

表一3の結果より, 䀣濁態 B P A と溶存態 B P A で の值にやや相違が見られるが，全 B P Aによる本団地 の 1 日当たりの排出負荷量は 189 333 mg/日となり, 平

表ー3 A団地における B P A排出負荷および原単位

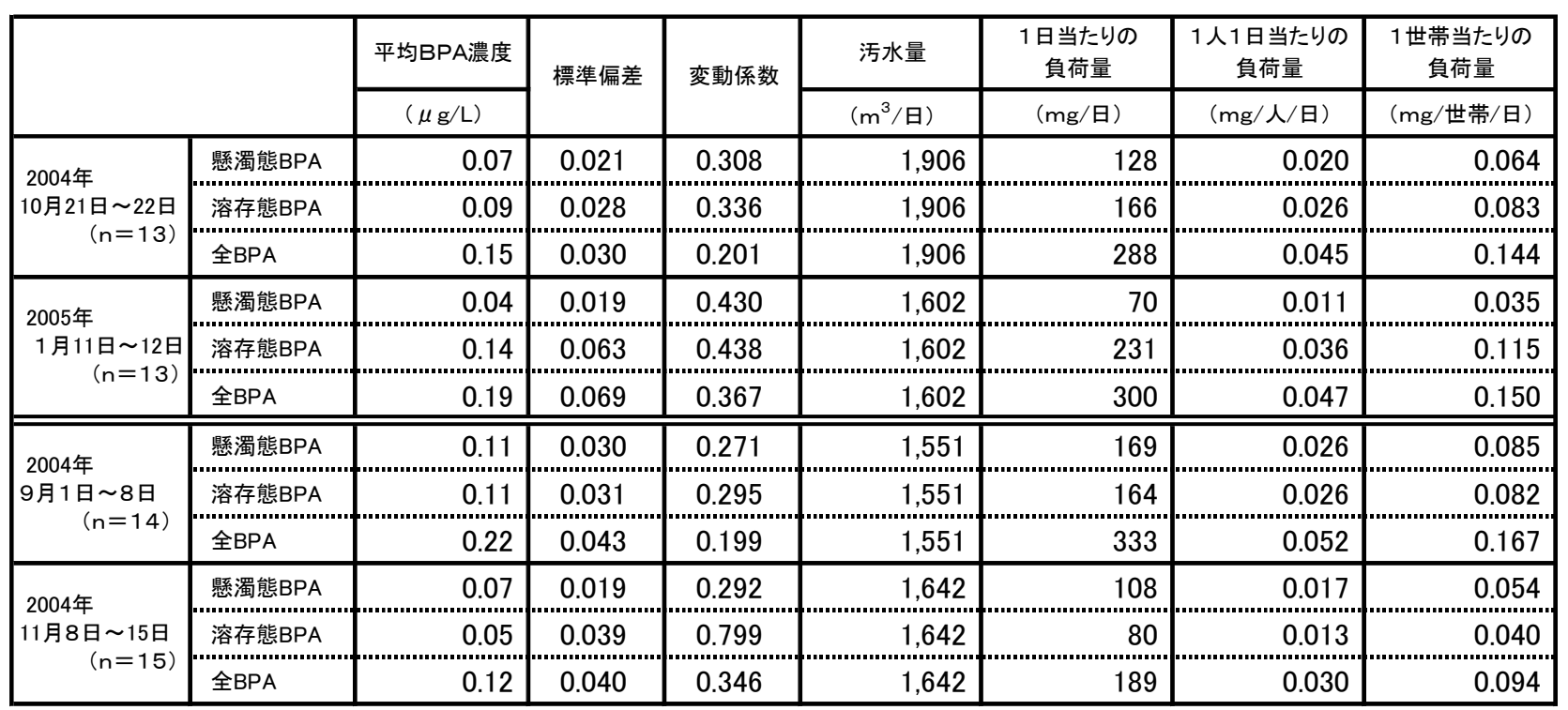

（注） $n=$ サンプル数 
表－4 A団地におけるBOD，COD，S S排出負荷および原単位

\begin{tabular}{|c|c|c|c|c|c|c|c|c|}
\hline & \multirow{2}{*}{$\frac{\text { 平均濃度 }}{(\mathrm{mg} / \mathrm{l})}$} & \multirow{2}{*}{ 標準偏差 } & \multirow{2}{*}{ 変動係数 } & \multirow{2}{*}{$\frac{\text { 污水量 }}{\left(\mathrm{m}^{3} / \text { 日) }\right.}$} & \multirow{2}{*}{$\begin{array}{c}\begin{array}{c}1 \text { 日当たりの } \\
\text { 負荷量 }\end{array} \\
(\mathrm{kg} / \text { 日 })\end{array}$} & \multirow{2}{*}{$\begin{array}{c}\text { 1人1日あ当たりの } \\
\text { 負荷量 }\end{array}$} & \multirow{2}{*}{$\begin{array}{c}\begin{array}{c}1 \text { 世帯当たりのの } \\
\text { 負荷量 }\end{array} \\
\text { (g/世帯/日) }\end{array}$} \\
\hline & & & & & & & & \\
\hline \multirow{3}{*}{$\begin{array}{l}\begin{array}{l}\text { 2004年 } \\
9 \text { 月 } 1 \text { 日 } \\
\quad(n=14\end{array} \\
\end{array}$} & BOD & 106 & 43 & 0.458 & 1551 & 164 & 26 & 82 \\
\hline & COD & 72 & 26 & 0.371 & 1551 & 112 & 18 & 56 \\
\hline & SS & 130 & 65 & 0.476 & 1551 & 202 & 32 & 96 \\
\hline \multirow{3}{*}{$\begin{array}{l}\text { 2004年 } \\
\text { 11月8日 } \\
\quad(n=15) \\
\quad(n=15)\end{array}$} & BOD & 135 & 38 & 0.287 & 1642 & 221 & 35 & 110 \\
\hline & COD & 82 & 20 & 0.257 & 1642 & 135 & 21 & 67 \\
\hline & SS & 134 & 38 & 0.282 & 1642 & 220 & 35 & 109 \\
\hline
\end{tabular}

均值として $277 \mathrm{mg} /$ 日が得られた. また， 1 人 1 日当た りの排出量は $0.030 \sim 0.052 \mathrm{mg} /$ 人/日となり, 平均值は $0.043 \mathrm{mg} /$ 人/日であった.

表－4のBOD，CODおよびS Sの排出原単位は， それぞれ 23〜34，17〜20，33〜34 g/人/日と，ほぼ従 来知られている值 ${ }^{15)}$ となり, 污水量ならびにB P A の 排出負荷の算定結果の妥当性を示寸一つの証左と考えら れた。

\section{（2）家庭内排水種別調査結果}

図－4は，家庭内で発生する各種排水を種別に採取し， B P A 濃度を測定した結果をまとめたものである. 食器 洗浄機排水からは $0.16 〜 0.22 \mu \mathrm{g} / \mathrm{L}$ ，シャワーの湯から は $0.02 \sim 0.03 \mu \mathrm{g} / \mathrm{L}$, 浴槽の湯からは $0.03 \sim 0.09 \mu \mathrm{g} / \mathrm{L}$ のB P Aが検出された. 洗濯機排水のB P A濃度は定量 下限以下であり，参考值であるが，0.001〜 0.008 $\mu \mathrm{g} / \mathrm{L}$ であった. 食器洗浄機排水中の B P A濃度は, 団地污水 を上回る值であり, 食器洗浄機内にB P A の溶出を生じ る部品が使用されていることを示唆しているが，食器洗 浄機内で使用される水がかなり高温であることにも関係 しているものと推測された.

\section{（3）トイレットペーパーからのB P A 溶出の検討}

前述したように団地污水中にはかなりの懸濁態 B P A が含まれているが，トイレットペーパーはその起源とな つていることが推測された. そこで，トイレットペーパ 一からの溶出だけではなく，ろ紙上の捕捉物に関しても 別に抽出を行い，両者のB P Aを分析した.

その結果, 図ー5に示すようにトイレットペーパー中 のB P A 量として 1.0〜 $147 \mu \mathrm{g} / \mathrm{kg}$ が得られ，紙原料に よってその值は大きく異なることが明らかとなった。す なわち, バージンパルプを原料としたトイレットペーパ 一のB P A 量は $1.0 〜 8.8 \mu \mathrm{g} / \mathrm{kg}$ と大きな差が見られな かったのに対し，古紙を原料としたトイレットペーパー で $4.1 \sim 147 \mu \mathrm{g} / \mathrm{kg}$ と顕著な差が認められた. 古紙を原 料としたトイレットペーパーで高い B P A 量が得られた 理由の一つとしては, インクやプリンターのトナーに顕

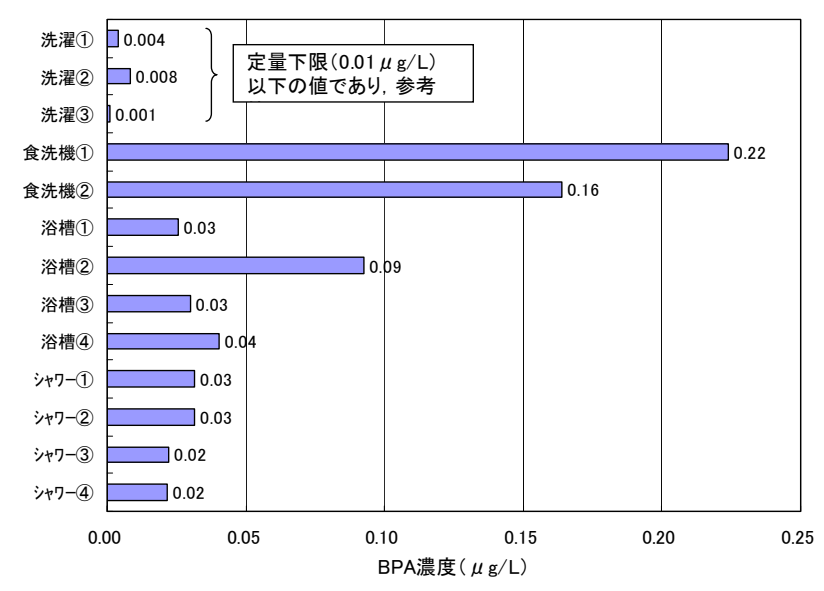

図－4＼cjkstart家庭における排水種別B P A濃度調査結果

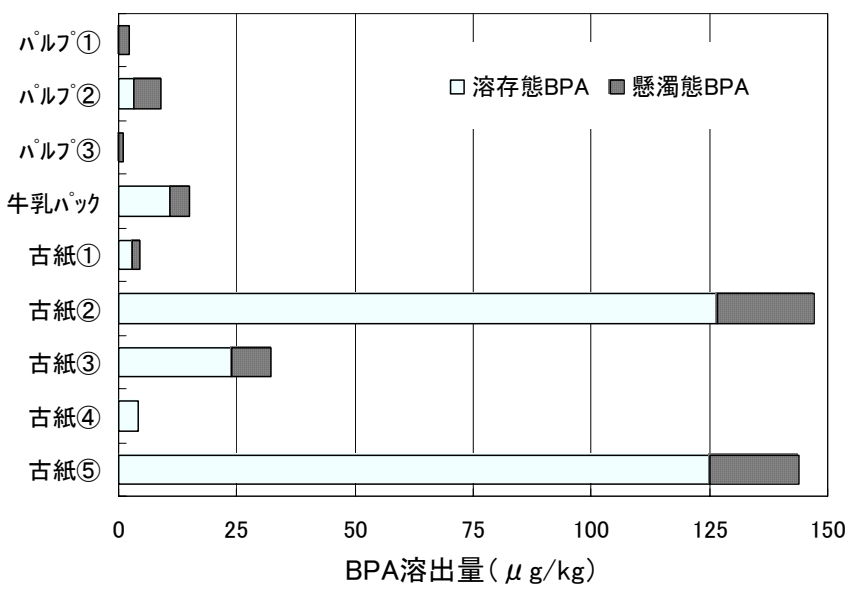

図ー5 トイレットペーパーを用いた攪找溶出試験結果

色剂等として使用されている B P Aが再生原料に混入し ている可能性 ${ }^{16)}$ が挙げられる. また, リサイクルする 過程で紙の繊維が短く, 脆くなることから, 紙としての 強度を高める目的などでB P Aが添加されている可能性 も考えられた。

\section{（4）A団地におけるB P A 排出負荷と排出源別B P A 負荷のバランスに関する検討}

本研究で得られた家庭内排水の種別調査結果ならびに 
表－5＼cjkstart家庭からのB P A排出負荷の推定結果

\begin{tabular}{|c|c|c|c|c|}
\hline & BPA濃度 & $\begin{array}{l}\text { 1日1人当たりの } \\
\text { 排出負荷量 }\end{array}$ & $\begin{array}{c}\text { A 団地1日当たりの } \\
\text { 排出負荷量 }\end{array}$ & \multirow[t]{2}{*}{ 備考 } \\
\hline & $(\mu \mathrm{g} / \mathrm{L})$ & $(\mu \mathrm{g} /$ 人·日 $)$ & $(\mathrm{mg} /$ 日) & \\
\hline A団地家庭排水 & 0.17 & 43 & 277 & 平均污水量：250 L/人-日 \\
\hline 風呂·シャワー & 0.04 & 2.4 & 15 & 使用水量：60 L/人·日 \\
\hline 食器洗浄機 & 0.22 & 0.2 & 1.1 & 25 L/世帯/日，普及率10\% \\
\hline 洗濯*1 & 0.008 & 0.3 & 2.0 & $40 \mathrm{~L} /$ 人·日 \\
\hline トイレットペーパー & $\begin{array}{l}0.066 \mu \mathrm{g} / \mathrm{g} \text { (古紙) } \\
0.004 \mu \mathrm{g} / \mathrm{g} \text { (バー } \\
\text { ジンパルプ) }\end{array}$ & 0.8 & 5.2 & $\begin{array}{c}\text { 男性: } 3.5 \mathrm{~m} / \text { 日,女性: } 12.5 \mathrm{~m} / \text { 日 }(2.3 \mathrm{~g} / \mathrm{m}) \\
\text { 古紙: } 65 \% \text {, バージンパルプ: } 35 \%\end{array}$ \\
\hline 尿 & $1.92 * 3$ & 2.9 & 18 & $1.5 \mathrm{~L} /$ 人·日 \\
\hline 種別BPA負荷計 & & 6.6 & $40 \sim 42^{* 4}$ & \\
\hline
\end{tabular}

$* 1:$ 検出下限以下の值であるため, 参考値である.

*2: 覮找溶出試験結果より, 古紙およびバージンパルプそれぞれを原料とするものの平均值を用いた

$* 3$ : 参考文献 11)より

* 4 : 参考値である洗濯排水の負荷を加えた場合

トイレットペーパーに関する試験結果をもとに，A団地 におけるこれらからのB P A排出負荷を算定した. 寸な わち，風呂排水に関しては，浴槽およびシャワーからの 排水の最大值 $0.09 \mu \mathrm{g} / \mathrm{L}$ 用い, 1 人 1 日当たりの使 用水量を前述の $60 \mathrm{~L} /$ 人/日として算出した場合で $35 \mathrm{mg} /$ 日，また平均值である $0.04 \mu \mathrm{g} / \mathrm{L}$ 用いた場合で $15 \mathrm{mg} /$ 日となった。洗濯排水に関しては，B P A測定值が定量 下限以下であるので参考值に止まるが，用水（排水）量 が $40 \mathrm{~L} /$ 人/日と風呂および氷洗便所に次いで多いので, 最大值である $0.008 \mu \mathrm{g} / \mathrm{L}$ を採用して算出したところ， $2.0 \mathrm{mg} /$ 日が得られた. 食器洗浄機排水については, 食 器洗浄での使用水量はカタログ值として概ね $15 \sim 25 \mathrm{~L}$ とされていることから，世帯数を 2,000 世帯，普及率を $10 \% ， 1$ 回の使用水量を $25 \mathrm{~L}$ と, 食洗機排水の B P A濃度として最大值の $0.22 \mu \mathrm{g} / \mathrm{L}$ を用いて, 1 日当たり のB P A負荷量を算出した結果, $1.1 \mathrm{mg} /$ 日となった. トイレットペーパーに関しては，その使用量が男性の場 合で $3.5 \mathrm{~m} /$ 日，女性の場合で $12.5 \mathrm{~m} /$ 日という資料 ${ }^{17)}$ が あり, 本研究での測定值からトイレットペーパー(シン グル)の単位重量として $2.3 \mathrm{~g} / \mathrm{m}$ を得ていることから, 本団地 (男性 3,100 人, 女性 3,300 人) での総使用量は $120 \mathrm{~kg} /$ 日と推定できる. したがって, トイレットペー パー中のB P A 量として, 最大值 $0.15 \mu \mathrm{g} / \mathrm{g}$ を用いる と, その 1 日当たりの負荷量は $18 \mathrm{~m} \mathrm{~g} /$ 日となるが, ト イレットペーパーの原料に占める古紙の割合が $65 \%{ }^{18)}$ とされていることから, 古紙が原料の試料の平均値 $0.066 \mu \mathrm{g} / \mathrm{g}$ およびバージンパルプが原料の試料の平均 值 $0.004 \mu \mathrm{g} / \mathrm{g}$ を用いて, 排出負荷を算定すると 5.2 $\mathrm{mg} /$ 日となる。 さらに，尿中の B P A 濃度に関しては
$1.92 \mathrm{ng} / \mathrm{mL}$ の報告 ${ }^{11)}$ があることから, 成人 1 人当たり の尿量を $1.5 \mathrm{~L} /$ 日として, 尿によるB P A負荷を 18 $\mathrm{mg} /$ 日と推定した.

A団地における総 B P A 排出負荷量をこれら排出源別 のB P A負荷量によって推計した結果, 表一 5 に示寸よ うに $42 \mathrm{mg} /$ 日と算定された. この值はA団地污水処理 場への総流入負荷量の平均值 $277 \mathrm{mg} /$ 日の $15.2 \%$ に相当 し，トイレットペーパーや各種排水以外の B P A 排出源 が存在することを示唆する結果となった. その一つとし て，水道水そのものへの含有が考えられるが，平成 10 年度における厚生省の調查結果 ${ }^{19)}$ では, 水道水原水で の最大值として $0.16 \mu \mathrm{g} / \mathrm{L}$ という值が報告されている が, 浄水では検出されたのが 26 浄水場のうち 2 浄水場 （最大值：0.11 $\mu \mathrm{g} / \mathrm{L}$ ）のみであり, 給水栓水では検出 された例はないとされている. また, 各種資材を試料と した溶出試験結果 ${ }^{20)}$, 21) から, 配管に用いられるような 硬質塩ビ管からのB P Aの溶出は認められなかったのに 対し，防錆等の目的で使用されるアクリル系樹脂塗料や エポキシ系樹脂塗料などからはB P Aの溶出を確認して いる.

本研究で調查対象とした団地においても, エポキシ樹 脂系の塗料や接着剂が排水管きょの内面等に使用されて いる可能性はある. 前述した浸漬溶出試験での結果では, エポキシ系樹脂塗料面から 24 時間の浸漬で $20 \mu \mathrm{g} / \mathrm{m}^{2}$ の B P A 溶出量を得ている ${ }^{211}$ 。この值をもとに, 本団 地（2000 世帯）におけるB P A排出量の排出源不明分 $235 \mathrm{mg} /$ 日について, このような面源での寄与を試算し てみると，1世帯当たり約 $5.9 \mathrm{~m}^{2}$ の面的排出源に相当 することになり, 内径 $10 \mathrm{~cm}$ の管きょに換算すると, 長 
さは $18.7 \mathrm{~m}$ となり，あり得なくはない管きょ長となる. しかしながら, 前提とした塗料面からのB P A溶出量は あくまでも 1 回 (24 時間) での調査結果であり,この 值が数年間という長期にわたって継続するかどうかは不 明である。

今後, 家庭内で発生寸るその他の排水に加え, 排水管 内面などの塗料やコーティング材, 接着剤などにも注目 した面的な B P A 排出源について, 長期的な溶出変動も 含めて明らかにしていく必要があると言える.

\section{4. おわりに}

本研究では，環境ホルモン作用や生殖毒性が疑われて いるビスフェノールAを注目物質として, 流域・地域で のリスク管理の観点から， B P Aの主として家庭からの 排出源・排出経路を明らかにすることを目的として検討 を行った. その結果, 以下のような主要な成果を得た.

（1）団地污水処理場の流入水の B P A 濃度は，0.14〜 $0.22 \mu \mathrm{g} / \mathrm{L}$ 程度であり, 䀣濁態のものが $50 \%$ 近く を占める場合も計測された。また，とくに顕著な 曜日間変動および時間変動は観測されなかった。

（2）調查対象としたA団地における B P A 排出負荷量 は，1日当たり 189〜333 mg/日と推定され，1人 1 日当たりの排出原単位は $0.030 \sim 0.052 \mathrm{mg} /$ 人/日 と算定された。

（3）家庭内の各種B P A 排出源に関して個別に評価を 行った結果，その総和は $42 \mathrm{mg} /$ 日と算定され，団 地污水処理場への流入負荷の $15.2 \%$ に相当し, 残 り 85\%のB P Aの排出源の説明は困難であった.

(4) 残りの $85 \%$ の P Aの排出に関しては, 検討を行 っていない資材からのものも当然考えられるが， 排水管きょ内面からのような面源の排出も想定す る必要が考えられた.

\section{参考文献}

1) Dmastra, T., Barlow, S., Bergman, A., Kavlock, R. and Kraak, G. V. D. (訳小林剛) : Global Assessment of the State - of-the-Science of Endocrine Disruptors.（WHO 環境ホルモンアセスメント 内分泌攪乱化学物質の科学的現状と国際的評価），エネ・ ティーエス, 2004. など.

2) 環境省環境管理局: 平成 13 年度「水環境中の内分泌攪乱 化学物質（いわゆる環境ホルモン）実態調査結果」，2003.

3) Yasuhara, A., Shiraishi, H., Nishikawa, M., Yamamoto, T., Nakasugi, O., Okumura, T., Kenmotsu, K., Fukui, H., Nagase, M. and Kawagoshi, Y.: Organic components in leachates from hazardous waste disposal sites, Waste Manage. Res., Vol.17,pp.186-197, 1999.

4) Urase, T. and Miyashita, K. : Factors affecting the concentration of bisphenol A in leachates from solid waste disposal sites and its fate in treatment processes, J. Mater. Cycles Waste Manag., Vol.5,pp.77-82, 2003.

5) 坂本広美, 福井博, 惣田昱夫, 金子栄廣 : 最終処分場浸出 水から検出されるビスフェノールAとその起源に関する研 究，廃棄物学会論文誌，Vol.15, No.6, pp.511-520, 2004.

6) 国土交通省都市・地域整備局下水道部: 平成 12 年度「下 水道における内分泌攪乱化学物質(環境ホルモン)に関する 調查報告」，2001.

7) 独立行政法人 製品評価技術基盤機構 ビスフェノール $\mathrm{A} リ$ スク評価管理研究会 : ビスフェノールAのリスク管理の現 状と今後のあり方，7-1〜7-2, 2005.

8) 同上, 8-42, 2005 .

9) 環境省平成 16 年度第 1 回内分泌攪乱化学物質問題検討会 : 「哺乳類を用いた人健康への内分泌攪乱作用に関する試験 結果と今後の方針について(案)」, 2004.

10) 津野洋, 西田薰: 環境衛生工学, p.54, 共立出版, 1995.

11) 深田秀樹, 森千里 : ヒトにおけるビスフェノール $\mathrm{A}$ 曝露の 現状, 環境ホルモン学会第 7 回要旨集, p.377, 2004.

12）日本規格協会：J I S K0450-1010「用水・排水中のビスフ エノール A試験方法」, 2000.

13）日本下水道協会 : 下水試験方法上巻, 1997.

14）独立行政法人 製品評価技術基盤機構 ビスフェノール $\mathrm{A} リ$ スク評価管理研究会 : ビスフェノールAのリスク管理の現 状と今後のあり方，2-2，2005.

15）社団法人日本下水道協会 : 流域別下水道整備総合計画調査 指針と解説, pp.28-29, 1990.

16) Vinggaard et al.: Identification and quantification of estrogenic compounds in recycled and virgin paper for household use as determined by an in vitro yeast estrogen screen and chemical analysis, Chem.Res.Toxicol., Vol.13, pp.1214-1222, 2002.

17) 平田純一：トイレットのなぜ?, p.22, 講談社, 1996.

18）浄化槽システム協会（JSA）:浄化槽とは-技術データ-JSA だより浄化槽とトイレットペーパー

(http:/www.jsa02.or.jp/01jyokaso/02 2p.html) .

19）国包章一: 平成 10 年度厚生科学研究費「内分必かく乱 化学物質の水道水からの曝露等に関する調査研究」報告 書,1999.

20) 今岡務, 保手濱勇聡 : 廃プラスチックおよびプラスチック 系資材からのビスフェノールAの溶出, 第 12 回廃棄物学 会研究発表会講演論文集, pp.1011-1013，2001.

21) 林香代子, 今岡務, 保手濱勇聡, 吉村友宏 : 建設資材等か らのビスフェノールAの溶出に関する検討, 第 55 回土木 学会中国支部研究発表会発表概要集, pp.581-582, 2003.

(2005.9.15受付) 


\title{
INVESTIGATION OF THE SOURCE AND THE PATH OF BISPHENOL-A DISCHARGED FROM A HOUSING DEVELOPMENT THROUGH DOMESTIC WASTEWATER
}

\author{
Tsutomu IMAOKA, Kayoko HAYASHI, Testuya UEDA \\ and Tomohiro YOSHIMURA
}

Bisphenol A (BPA) is a chemical organic compound that is used as the material of plastic products and is suspected endocrine disruptors action (environmental hormones action). This study aimed to clarify the source and path of BPA discharged from a housing development through domestic wastewater. The mean concentrations of BPA in inflow investigated by 1 -week research and 24 hours research at wastewater treatment facility of A-housing development in Hiroshima Prefecture were in the range of $0.12-0.22 \mu$ $\mathrm{g} / \mathrm{L}$. The particulate fraction accounted for approximate half of total BPA in the wastewater. The discharge load of BPA from A-housing development was calculated to be $189-333 \mathrm{mg} / \mathrm{day}$. On the other hand, BPA discharge load from several kinds of domestic wastewater in home such as the effluents from a washing machine and a dishwasher were studied and it was estimated that the sum of the investigated individual BPA discharge was equivalent to $15 \%$ of the inflow load to the wastewater treatment facility mentioned above. Therefore, it was suggested that the investigations of the nonpoint emission source of BPA such as the inside of drainpipe were necessary. 